\title{
Identification and characterization of proteins synthesized de novo and secreted by the reproductive tract of the American alligator, Alligator mississippiensis
}

\author{
W. C. Buhi ${ }^{1,2,3}$, I. M. Alvarez', M. Binelli ${ }^{4}$, E. S. Walworth ${ }^{2}$ and L. J. Guillette, Jr ${ }^{5}$ \\ Departments of ${ }^{1}$ Obstetrics and Gynecology, ${ }^{2}$ Biochemistry and Molecular Biology, ${ }^{3}$ Animal Science, ${ }^{4}$ Dairy and Poultry Science, \\ and ${ }^{5}$ Zoology, University of Florida, Gainesville, FL 32610-0294, USA
}

\begin{abstract}
The objectives of this study were to identify, characterize and examine differences in proteins synthesized de novo and secreted by different regions of the reproductive tract of the American alligator, Alligator mississippiensis, during three reproductive (vitellogenic, gravid, post-clutch) and one non-reproductive state. After capture, alligators from lakes in north central Florida were anaesthetized, the reproductive tract excised aseptically, the size of any follicle determined, and different functional regions of the tract dissected out and partitioned for explant culture. Analysis of the biosynthetic activity indicated regional variations within the tract, differences among reproductive groups and region by status interactions. When oviductal regions were considered regardless of reproductive status, the greatest incorporation of $\left[{ }^{3} \mathrm{H}\right] \mathrm{Leu}$ into secreted nondialysable macromolecules was by the anterior and posterior infundibulum and oviductal tube compared with the transition zone and the uterus. When status was included, the biosynthetic activity of the anterior and posterior portion of the tract in non-reproductive alligators was not different, whereas that of the posterior region of the reproductive group (vitellogenic, gravid, post-clutch) was significantly lower than that of the anterior region. This finding indicates that regulation of protein synthesis and secretion by the non-reproductive alligator tract is different from that in the tract of the reproductive group. Explant-conditioned media were analysed by one-dimensional and two-dimensional SDS-PAGE and fluorography. Sixteen major proteins in culture media were identified as de novo synthesized, by relative molecular weight, by isoelectric point and by differences in distribution determined for reproductive status and oviductal region. Six proteins were examined by N-terminal amino acid microsequence analysis. On the basis of a 29 amino acid sequence, the major oviductal protein, alligator protein 1 (aP1: $M_{\mathrm{r}} 55000$, basic), found in the infundibulum and tube of vitellogenic alligators, was identical to the major protein isolated from alligator egg albumen. Four proteins (aP4-aP7) were sequenced and shown to be significantly related to immunoglobulin heavy chains from several species. This study demonstrated that a large number of proteins are synthesized de novo and released by the female alligator reproductive tract and that there are biosynthetic activity differences by reproductive status and region. Six proteins have been identified, several of which may be incorporated into alligator egg albumen and some of which appear to be different from proteins found in the egg albumens of other species.
\end{abstract}

\section{Introduction}

The resurgence of wild alligator populations after their endangered species classification in 1975 has led to their reclassification and the consequent development of a multimillion dollar farm industry in the southeastern United States. With these developments came the recognition that

Received 20 April 1998.

many aspects of reproduction in this species were still unknown. The first in-depth data on the reproductive cycle of the alligator were reported 25 years ago (for reviews, see Joanen and McNease, 1989; Lance, 1989; Guillette ct al., 1997). Data on wild populations show that breeding cycle, oviposition date, clutch size, and hatching rates correlate with temporal and geographical differences Joanen and McNease, 1989; Lance, 1989; Woodward et al., 1989; Palmer and Guillette, 1992; Guillette et al., 1997). 


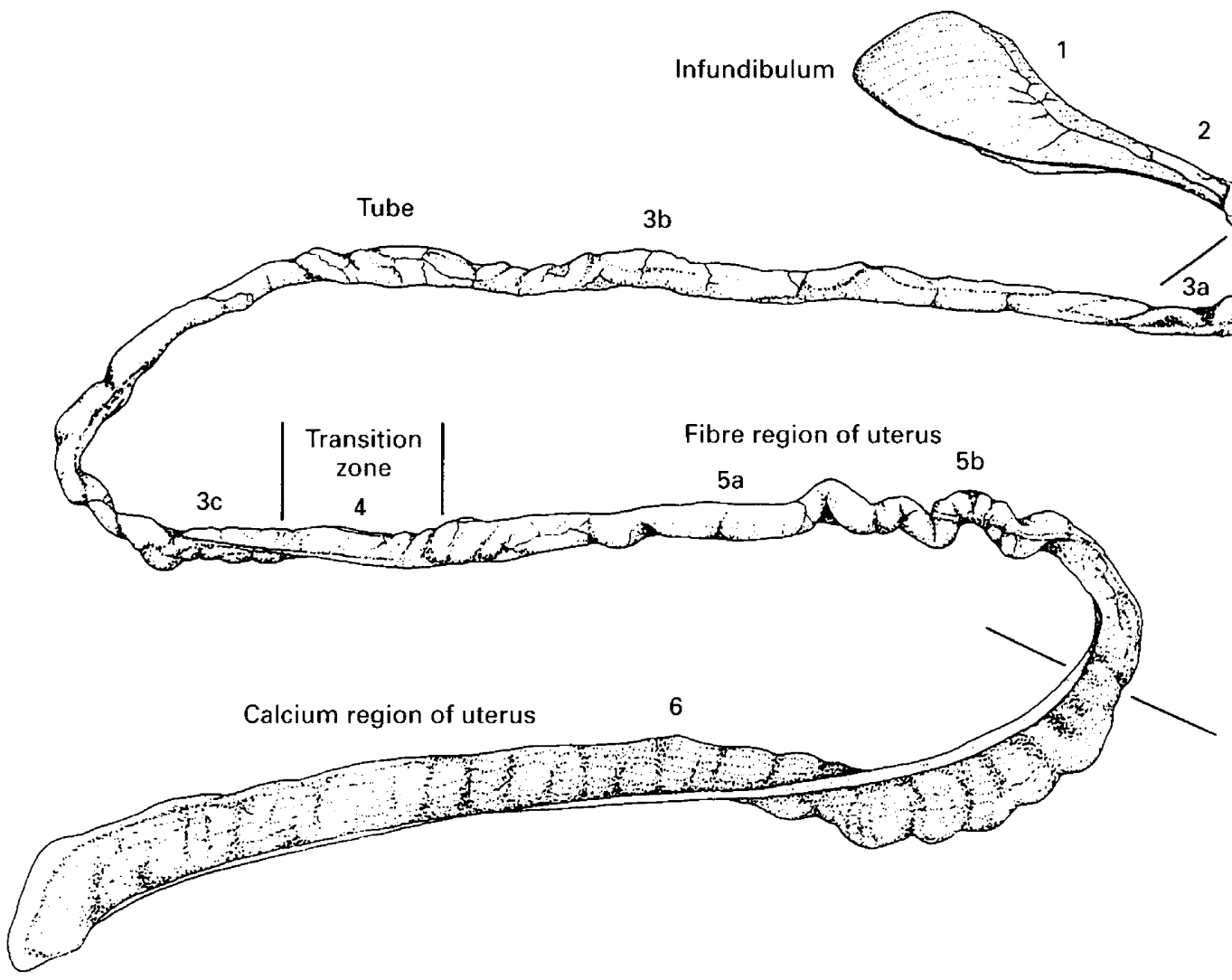

Fig. 1. Schematic representation of the female reproductive tract of the American alligator, Alligator mississippiensis. Diagram shows the regions of the oviduct: (1) anterior infundibulum; (2) posterior infundibulum; (3a) upper tube; (3b) middle tube; (3c) lower tube; (4) tubo-uterine junction; (5a) upper anterior uterus fibre region; (5b) middle anterior uterus fibre region; and (6) posterior uterus calcium region. Labelling represents regions from which tissues were cultured and analysed by two-dimensional SDS-PAGE and fluorography. (Reprinted with permission from Palmer and Guillette, 1992.)

Knowledge regarding the gross and cellular anatomy of the female reproductive tract during the breeding cycle (Lance, 1989) has been enhanced by studies on the functional morphology and ultrastructure of late-vitellogenic and gravid specimens (Palmer and Guillette, 1992). The reproductive tract can be divided into seven distinct regions on the basis of histological and ultrastructural data (see, Palmer and Guillette, 1992; Fig. 1): anterior infundibulum, posterior infundibulum, tube, aglandular transition region (tubouterine junction), anterior uterus, posterior uterus and vagina. The infundibulum is structurally similar and identically named across most species. Although there are no glands in this region, secretory cells are clearly visible. The alligator tube appears to be homologous with the avian magnum as these are structurally similar and both secrete albumen (egg white) proteins. Proteinaceous fibres of the eggshell membrane are secreted by the anterior uterus of the alligator and the avian isthmus, which appear similar in structure and developmentally homologous. The alligator posterior uterus resembles the shell gland of birds in structure and also appears to function in the formation of the calcareous eggshell.

The reproductive activity of female alligators is associated with changes in plasma sex hormone concentrations. Increased plasma oestrogen concentrations are correlated with reproductive tract hypertrophy, growth of ovarian follicles and vitellogenesis (Lance, 1989; Guillette et al., 1997). Furthermore, in vitellogenic females, plasma testosterone concentrations are increased, whereas plasma sex-steroid binding protein concentrations are decreased. Testosterone appears to be necessary for reproductive tract development in the avian system and may function similarly in alligators (Lance, 1989; Guillette et al. 1997). In addition, both oestrogen and progesterone may regulate albumen synthesis by the reproductive tract. Guillette et al. (1997) report a double wave of follicular growth that implies that the early population of enlarged follicles, which subsequently becomes atretic, serves to increase plasma oestrogen concentrations and, thus, maximize reproductive tract hypertrophy and hyperplasia. Furthermore, ovulation is immediately preceded by a transient, progesterone surge (Lance, 1989; Guillette et al., 1995) which is subsequently maintained during the 3.0-3.5 weeks between ovulation and oviposition. Egg albumen, a complex mixture of proteins (Palmer and Guillette, 1991; Alvarez et al. 1992), and eggshell membrane proteins are also deposited during this time period (Lance, 1989). These egg 
components provide the developing embryo with a relatively homeostatic environment during nesting (Palmer and Guillette, 1991).

While these reproductive events in alligators indicate endocrine control, the hormonal influences on oviductal protein synthesis and secretion during the different reproductive states remain to be investigated. During vitellogenesis, increased plasma oestrogen concentrations induce hepatic vitellogenin production. The vitellogenin is secreted, transported in the blood and incorporated into the preovulatory oocyte. Little is known about the concurrent events in the reproductive tract.

A good understanding of reproduction and egg formation in alligators is lacking, including information on the complex composition of egg albumen, its derivation and function. Therefore, the objectives of this study were: (1) to examine the biochemical milieu of the alligator oviduct at four different reproductive states; (2) to examine the biosynthetic activity by region and reproductive status; (3) to characterize by electrophoresis the distribution of proteins synthesized de novo and secreted; (4) to determine the uniqueness and distribution of protein by reproductive status and by region; and (5) to purify and identify the major proteins synthesized. Throughout this paper, the term 'oviduct' will be used in a comparative anatomical sense to refer to the entire alligator female reproductive tract that is derived from the embryonic Müllerian duct.

\section{Materials and Methods}

\section{Materials}

Ultrapure acrylamide, $N, N^{\prime}$-diallyltartardiamide, urea, Nonidet P40, agarose and sodium dodecyl sulfate were purchased from Gallard-Schlesinger, Carle Place, NY. Electrophoresis grade $N, N, N^{\prime}, N^{\prime}$-tetramethylethylenediamine was obtained from Schwarz-Mann Biotech, Cleveland, $\mathrm{OH}$. Ampholines were from Pharmacia LKB, Piscataway, NJ. Scientific imaging film, $X$-Omat $A R$, and photography reagents were supplied by Eastman Kodak Co., Rochester, NY. Protein standards, chemistry diagnostic kits and reagents, and amino acids were obtained through Sigma Chemical Co., St Louis, MO. The oestradiol radioimmunoassay kit was a product of Diagnostic Products Corp., Los Angeles, CA. Minimal essential culture medium (MEM) and reagents were purchased from Life Technologies, Inc., Grand Island, NY. Radiolabelled L-[4,5-3 H]leucine (sp. act. $120 \mathrm{Ci} \mathrm{mmol}{ }^{-1}$ ) was obtained from Amersham Corporation, Arlington Heights, IL. All other electrophoresis, tissue culture and laboratory supplies were obtained from either Bio-Rad Laboratories, Richmond, CA, Fisher Scientific, Orlando, FL, or Cole-Parmer Instrument Co., Niles, IL.

\section{Animals}

Under permit from the Florida Game and Freshwater Fish Commission, mature alligators (Alligator mississippiensis) were captured from wild populations in central Florida lakes during March-July of 1989-1993. Blood samples for analysis of calcium, inorganic phosphorus, albumin, oestradiol and total protein concentration were collected within $10 \mathrm{~min}$ of capture and body measurements were recorded. Surgery was performed the next day (see below) at the University of Florida and on the basis of the presence or absence of follicles, ovarian follicle size, the presence or absence of eggs, the characteristics of eggs and blood analysis of oestradiol, calcium, phosphorus, serum albumin and total protein, alligators were divided into four groups: vitellogenic (reproductively active before ovulation), gravid (reproductively active after ovulation), post-clutch and nonreproductive. The classification of seven alligators as vitellogenic was later confirmed by electrophoretic analyses.

\section{Tissue collection and explant cultures}

Within $24 \mathrm{~h}$ of capture, animals were anaesthetized with $20 \mathrm{mg}$ sodium pentobarbital $\mathrm{kg}^{-1}$ body weight and the reproductive tracts were removed surgically under sterile conditions. Tissue was harvested along the entire oviduct (see Fig. 1) at intervals of $8-15 \mathrm{~cm}$, for explant culture. The tissue dissected free of connective tissue was cultured at $32^{\circ} \mathrm{C}$, as described by Buhi et al. (1989a, 1990). On the basis of animal reproductive status, 14-20 separate tissue explant cultures, encompassing the different functional regions of the oviduct (Palmer and Guillette, 1992), were derived from the reproductive tract of each animal.

\section{Alligator and chicken egg albumen}

Eggs were collected from gravid female alligators at surgery (see above) for analysis. Chicken eggs were purchased commercially. For both types of egg, the entire albumen was separated from the yolk and shell, frozen in liquid $\mathrm{N}_{2}$, lyophilized, ground with a mortar and pestle, and stored desiccated at $-20^{\circ} \mathrm{C}$. For electrophoretic analysis, appropriate amounts of egg albumen were weighed, suspended in solubilization buffer and treated as described by Buhi et al. (1989a).

\section{Determination of protein synthesis de novo}

Secretory proteins synthesized de novo and released into the culture medium by tissue explants were detected by the incorporation of [ $\left.{ }^{3} \mathrm{H}\right] \mathrm{Leu}$ into total nondialysable macromolecules as described by Buhi et al. (1989a, 1990). Briefly, $500 \mathrm{mg}$ tissue was placed in $15 \mathrm{ml}$ Leu-deficient $\mathrm{MEM}$ in the presence of $100 \mu \mathrm{Ci}\left[{ }^{3} \mathrm{H}\right] \mathrm{Leu}$ and incubated at $32^{\circ} \mathrm{C}$ in a defined atmosphere for $24 \mathrm{~h}$. After cessation of culture, the supernatants were centrifuged free of cellular debris at $2200 \mathrm{~g}$ for $10 \mathrm{~min}$ at $4^{\circ} \mathrm{C}$, dialysed and radioactivity was determined. The biosynthetic activity of the tissue, defined as the rate of incorporation of $\left[{ }^{3} \mathrm{H}\right] \mathrm{Leu}$ into nondialysable macromolecules, was presented as d.p.m. $\times 10^{-4}$ per mg wet tissue per $24 \mathrm{~h}$. In these studies, after an initial lag period, incorporation was linear through $30 \mathrm{~h}$ and 
$<12 \%$ of available [ $\left.{ }^{3} \mathrm{H}\right]$ Leu was incorporated into nondialysable macromolecules. Concurrently, the protein content of dialysed conditioned medium was determined spectrophotometrically using the microassay procedure according to manufacturer's instructions (Bio-Rad Laboratories, Richmond, CA).

\section{One-and two-dimensional polyacrylamide gel electrophoresis and western blotting}

Identification and characterization of proteins synthesized de novo and released by tissue explant cultures was performed by one- and two-dimensional SDS-PAGE. For one-dimensional SDS-PAGE, aliquots of dialysed conditioned culture media were lyophilized, resuspended in solubilization buffer, and proteins were separated as described by Buhi et al. (1989a). Two-dimensional SDS-PAGE (Roberts et al., 1984; Buhi et al., 1990) resolved proteins $(\mathrm{pI}<8.5)$ by isoelectric focusing in the first dimension and by molecular weight in the second dimension. Aliquots of dialysed conditioned culture medium containing 50000 c.p.m. were lyophilized, resuspended in solubilization buffer and applied to isoelectric focusing gels. Tube gels were then equilibrated, affixed to $10 \%$ second-dimension slab gels, and proteins separated under constant current. Fluorographs from two-dimensional SDS-PAGE gels were prepared as described by Buhi et al. (1990).

Alternatively, for immunoblot or amino acid microsequence analysis, proteins were separated using Tristricene gels (Schägger and von Jaqow, 1987). These twodimensional SDS-PAGE gels were equilibrated in deionized water $\left(\mathrm{dH}_{2} \mathrm{O}\right)$ and proteins were transferred to Immobilon polyvinylidene fluoride (PVDF) membranes with stepwise increases in current to a final $2.5 \mathrm{~mA}$ per $\mathrm{cm}^{2}$ in a transfer apparatus (Millipore Milliblot system). After transfer, membranes were placed in $\mathrm{dH}_{2} \mathrm{O}$ containing $0.02 \%(\mathrm{w} / \mathrm{v})$ $\mathrm{NaN}_{3}$. Membranes containing proteins to be sequenced were stained in $0.01 \%(\mathrm{w} / \mathrm{v})$ Coomassie blue in $50 \%(\mathrm{v} / \mathrm{v})$ methanol, destained in $50 \%(\mathrm{v} / \mathrm{v})$ methanol, rinsed in $\mathrm{dH}_{2} \mathrm{O}$ containing $0.02 \%(\mathrm{w} / \mathrm{v}) \mathrm{NaN}_{3}$, and stored at $-20^{\circ} \mathrm{C}$ until sequenced.

\section{$N$-terminal amino acid microsequencing and amino acid analysis}

Intact proteins on PVDF membranes were N-terminal amino acid microsequenced by the Protein Chemistry Core Facility of the Interdisciplinary Center for Biotechnology Research (ICBR) at the University of Florida using an Applied Biosystem Model 470A gas phase protein sequencer with an on-line analytical HPLC system. Sequence data were analysed and compared with data from the National Biomedical Research Foundation (NBRF, Washington, DC) protein database and the GenBank Genetic Sequence Database (Intelligenetics, Mountain View, CA) using FASTA and TFASTA programs (Pearson and Lipman, 1988) or BLAST P (Altschul et al., 1990).

\section{Oligopeptide synthesis and antibody production}

A rabbit polyclonal antiserum was raised against a 12-mer synthetic oligopeptide (CEARINQAALDY) which was synthesized by the Protein Chemistry Core of the ICBR. This sequence represents residues 5-16 of the N-terminal amino acid sequence of the alligator infundibulum protein, alligator protein 1 (aP1). The oligopeptide was coupled to keyhole limpet hemocyanin (KLH) according to the manufacturer's instructions (Amject Activated Immunogen Conjugation Kit, Pierce Chemical Co., Rockford, IL) for immunization (Ogilvie et al., 1990). Preimmune serum was obtained and then male New Zealand White rabbits were injected s.c. with $300 \mu \mathrm{g}$ conjugated peptide emulsified in complete Freund's adjuvant. All booster injections used incomplete Freund's adjuvant. Immune serum was obtained following standard protocols (Ogilvie et al., 1990).

\section{Immunoblot analysis}

PVDF membranes, previously rinsed and stored in deionized water containing $0.02 \%(\mathrm{w} / \mathrm{v}) \quad \mathrm{NaN}_{3}$, were incubated in TBS blocking buffer $\left(20 \mathrm{mmol}\right.$ Tris- $\mathrm{HCl}{ }^{-1}, 3 \%$ $(\mathrm{w} / \mathrm{v})$ gelatin, $\left.0.5 \mathrm{~mol} \mathrm{NaCl}^{-1}, \mathrm{pH} 7.5\right)$ and washed in TBS containing $0.05 \%(\mathrm{v} / \mathrm{v})$ Tween-20 (TTBS). Blots were then immersed in incubation buffer (TTBS) containing either rabbit anti-oligopeptide serum or preimmune rabbit serum (NRS) at a 1:200 dilution for $2 \mathrm{~h}$ at room temperature. After washing in TTBS, binding of rabbit anti-oligopeptide antiserum was detected using goat anti-rabbit horseradish peroxidase conjugate with diaminobenzidine metalenhanced colour reaction (Harlow and Lane, 1988; Ogilvie et al., 1990).

\section{Plasma chemistry determination}

Plasma concentrations of total protein, albumin, calcium, and inorganic phosphorus were assayed spectrophotometrically using commercially available kits according to manufacturer's instructions (Sigma; Bio-Rad). Oestradiol concentrations in plasma were measured by a previously validated radioimmunoassay (Guillette et al., 1997). Plasma vitellogenin concentrations were determined by onedimensional SDS-PAGE in Coomassie blue-stained, $7.5 \%$ resolving minigels containing molecular weight standards and a vitellogenin standard as described by Guillette $e t$ al. (1997). Chemical and physical data were used to classify the reproductive state of animals (Guillette et al., 1996, 1997) (data not shown).

\section{Statistical analysis}

The rate of incorporation of radioactivity $\left(\left[{ }^{3} \mathrm{H}\right] \mathrm{Leu}\right)$ into nondialysable macromolecules was examined by least squares means analysis of variance, using the general linear models procedure of the Statistical Analysis System (SAS Users Guide, 1989). Values with $P<0.1$ were considered Downtoaded from Bioscientifica.com at 04/26/2023 12:50:09PM 
Table 1. Least squares means \pm SEM of the incorporation rate of $\left[{ }^{3} \mathrm{H}\right]$ Leu (d.p.m. $\times 10^{-4}$ per mg wet tissue weight per $24 \mathrm{~h}$ ) into nondialysable macromolecules by oviductal tissue of alligators

\begin{tabular}{lcccccc}
\hline & \multicolumn{5}{c}{ Region } \\
\cline { 2 - 7 } $\begin{array}{l}\text { Reproductive } \\
\text { status }\end{array}$ & $\begin{array}{c}\text { Anterior } \\
\text { infundibulum }\end{array}$ & $\begin{array}{c}\text { Posterior } \\
\text { infundibulum }\end{array}$ & Tube & $\begin{array}{c}\text { Tubo-uterine } \\
\text { junction }\end{array}$ & $\begin{array}{c}\text { Anterior } \\
\text { uterus }\end{array}$ & $\begin{array}{c}\text { Posterior } \\
\text { uterus }\end{array}$ \\
\hline Non-reproductive & $1.02 \pm 0.21$ & $1.30 \pm 0.2$ & $0.62 \pm 0.1$ & $1.46 \pm 0.2$ & $1.04 \pm 0.1$ & $0.95 \pm 0.1$ \\
Vitellogenic & $0.92 \pm 0.1$ & $1.57 \pm 0.1$ & $0.98 \pm 0.05$ & $0.93 \pm 0.1$ & $0.81 \pm 0.1$ & $0.70 \pm 0.1$ \\
Gravid & $0.83 \pm 0.2$ & $0.93 \pm 0.2$ & $0.63 \pm 0.1$ & $0.62 \pm 0.2$ & $0.68 \pm 0.1$ & $0.74 \pm 0.1$ \\
Post-clutch & $0.97 \pm 0.2$ & $0.98 \pm 0.2$ & $0.43 \pm 0.1$ & $0.76 \pm 0.2$ & $0.70 \pm 0.1$ & $0.55 \pm 0.1$ \\
\hline
\end{tabular}

Table 2. Mean comparisons among region, status and region $\times$ status interactions and selected orthogonal contrasts of the least squares means of $\left[{ }^{3} \mathrm{H}\right]$ Leu incorporation rate into nondialysable macromolecules by alligator oviductal tissue

\begin{tabular}{rll}
\hline Contrast & Comparison & Significance \\
\hline 1 & NR versus (V + G + PC) & $P<0.07$ \\
2 & V versus (G + PC) & $P<0.07$ \\
3 & G versus PC & Not significant \\
4 & (ANT INF + POST INF + T) versus (TZ + ANT UT + POST UT) & $P<0.07$ \\
5 & ANT INF versus (POST INF + T) & Not significant \\
6 & POST INF versus T & $P<0.01$ \\
7 & TZ versus (ANT UT + POST UT) & $P<0.07$ \\
8 & ANT UT versus POST UT & Not significant \\
9 & 1 versus 4 & $P<0.01$ \\
10 & 1 versus 7 & $P<0.05$ \\
11 & 2 versus 5 & $P<0.07$ \\
\hline
\end{tabular}

NR: non-reproductive; V: vitellogenic; G: gravid; PC: post-clutch; ANT INF: anterior infundibulum; POST INF: posterior infundibulum; T: tube; TZ: tubo-uterine junction; ANT UT: anterior uterus; POST UT: posterior uterus.

Other contrasts that were not significant are not included in table.

significant. The statistical model used status (nonreproductive (NR), vitellogenic $(\mathrm{V})$, gravid $(\mathrm{G})$, and postclutch $(\mathrm{PC})$ ), alligator (within status), region (anterior infundibulum: ANT INF; posterior infundibulum: POST INF; tube: T; tubo-uterine junction: TZ; anterior uterus: ANT UT; and posterior uterus: POST UT) and all higher order interactions. The main effect of status was tested against alligator (within status) as the error term. A set of preplanned orthogonal contrasts was used to examine differences among reproductive statuses, regions and status $\times$ region interactions. Status contrasts were: NR versus $V, G$ and PC; $V$ versus $G$ and PC; $G$ versus PC. Region contrasts were: ANT INF, POST INF and T versus TZ, ANT UT and POST UT; ANT INF versus POST INF and T; POST INF versus T; TZ versus ANT UT and POST UT; and ANT UT versus POST UT.

\section{Results}

\section{Biosynthetic activity}

All tissues cultured, regardless of region or status, incorporated $\left[{ }^{3} \mathrm{H}\right] \mathrm{Leu}$ in vitro into newly synthesized, nondialysable macromolecules that were released into the medium. The results of analysis of variance demonstrated that biosynthetic activity (rate of $\left[{ }^{3} \mathrm{H}\right] \mathrm{Leu}$ incorporation) in vitro was significantly different between histologically and ultrastructurally different oviductal regions and alligator reproductive status $(P<0.01)$ but not by the main effect of status alone $(P>0.1)$. Specific comparisons examined using orthogonal contrasts showed that, across all regions (main effect of status), in vitro biosynthetic activity was greater in the non-reproductive group compared with the reproductive group (vitellogenic, gravid, post-clutch) $(P<0.07$; Tables 1 and 2). In addition, oviductal tissue from vitellogenic alligators had a greater biosynthetic activity than did tissue from gravid or post-clutch animals $(P<0.07)$. The biosynthetic activity of the anterior portion of the tract tended to be greater than that of the posterior portion and, within the anterior portion, the biosynthetic activity of the posterior infundibulum was greater than that of the tube (Table 2).

Significant main effect comparisons must be interpreted carefully since there was a significant effect of status $\times$ region interaction on the biosynthetic activity $(P<0.01)$. Orthogonal contrast analyses of status by region interactions are shown (Table 2). The results indicate that biosynthetic activity of non-reproducing alligators across all oviductal regions is not different. However, activity was shown to be greater in the anterior of the tract than in the posterior portion for 
(a)

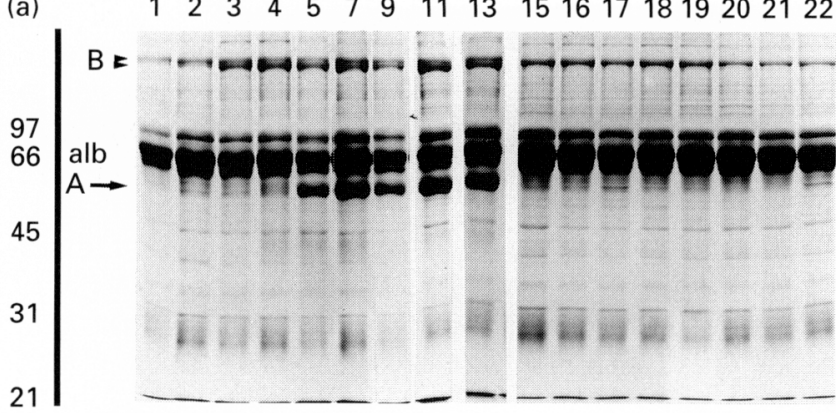

(b)

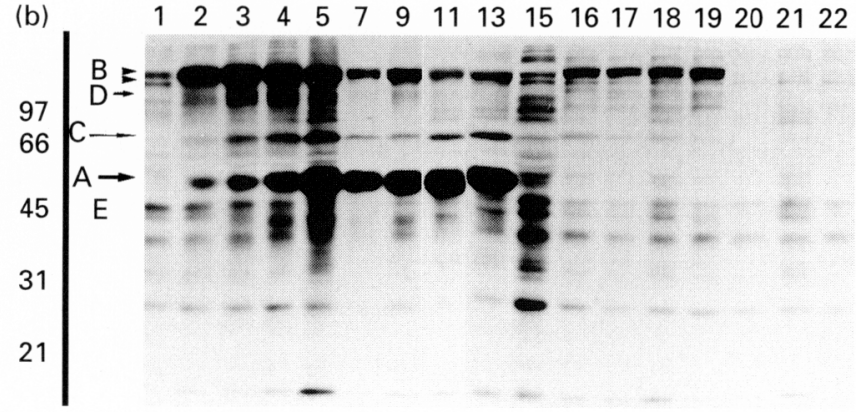

Fig. 2. Representative Coomassie blue-stained one-dimensional SDS-PAGE and fluorographic analysis of explant culture media conditioned by tissue from the reproductive tract of a vitellogenic alligator, Alligator mississippiensis. (a) Sequential tissue explants from lanes 1,2: anterior infundibulum; lanes 3,4: posterior infundibulum; lanes 5,7,9,11 and 13: tube; lane 15: tubo-uterine junction; lanes 16-18: anterior uterus; and lanes 19-22: posterior uterus, with $125 \mu l$ media protein loaded per lane. Band labelled alb indicates the position of serum albumin. (b) Representative fluorograph as in (a) but prepared from a companion one-dimensional SDS-PAGE gel with $62.5 \mu \mathrm{l}$ media protein loaded per lane. Bands A, B and C indicate three major Coomassie blue-stained and radiolabelled bands at $55000 M_{r}, 125000 M_{r^{\prime}}$ and $76000 M_{r}$, respectively. Bands D and $\mathrm{E}$ were not detected by Coomassie staining. Molecular mass standards ( $\mathrm{kDa}$ ) are indicated.

vitellogenic, gravid, and post-clutch animals (Table 2). While the result of contrast 10 indicates that the biosynthetic activity of all regions in the posterior portion in vitellogenic, gravid, and post-clutch alligators was similar, the activity of the tubo-uterine junction was shown to be greater $(P<0.05)$ than that of the anterior uterus and the posterior uterus in nonreproducing animals. Other analyses indicate that activity in the anterior infundibulum was similar among vitellogenic, gravid and post-clutch animals. However, the activity in the posterior infundibulum was significantly greater in vitellogenic alligators than it was in gravid and post-clutch animals. Overall, these analyses indicate that the biosynthetic activity of combined and specific regions within the oviduct and specific status are regulated in a different way.

\section{One-dimensional SDS-PAGE}

Qualitative changes in the patterns of polypeptides released into culture medium were examined in vitellogenic alligators first by one-dimensional SDS-PAGE. Representative
Coomassie blue staining (Fig. 2a) and fluorography (Fig. 2b) of multiple explant culture media conditioned by different regions of the oviduct from a vitellogenic alligator are shown. While several of the Coomassie blue-stained bands appeared to resemble both avian and mammalian serum proteins, such as albumin, one band (Fig. 2a,b; $55 \mathrm{kDa}$ ), found only in infundibulum- (lanes 1-4) and tubeconditioned (lanes 5-13) media, appeared to intensify from anterior to posterior regions of the tract. The intensity of this band was greater in the tube than it was in other regions. Fluorography (Fig. 2b) confirmed de novo synthesis of this protein in the tube and infundibulum. Fluorography and Coomassie blue staining further indicated the presence of two major proteins, of about $76 \mathrm{kDa}$ and $125 \mathrm{kDa}$, in the infundibulum and upper tube. However, the intensity was greater in the infundibulum than it was in the tube. None of these proteins appeared to be found in the tubo-uterine junction or the uterus, indicating differential synthesis and secretion. One other protein (Fig. 2b; $110 \mathrm{kDa}$ ), found by fluorography, but not by Coomassie blue staining, also appeared to be restricted to the infundibulum and upper tube. A number of other proteins (Fig. 2b) less intensely labelled, were similarly synthesized de novo and released by the oviduct.

The $55 \mathrm{kDa}$ band (band a; Fig. 2a, lanes 5-13; Fig. 2b, lanes 2-13; Fig. 3a,b, lane 2) which corresponds to a major alligator egg albumen band (Fig. 3a, lane 4) was not found in chicken egg albumen (Fig. 3a, lane 5). The $125 \mathrm{kDa}$ band (band b; Figs $2 a, b$ and $3 a$ ) appears to be found in both alligator and chicken egg albumen (Fig. 3a, lanes 4 and 5). The $76 \mathrm{kDa}$ band (band c; Figs $2 b$ and $3 a, b$ ) was found in alligator egg albumen (Fig. 3a, lane 4) but not in chicken egg albumen (Fig. 3a, lane 5), although a major band of slightly lower $M_{r}$ was found. Band e, composed of several proteins (Fig. $2 b$, lanes 1- 5; Fig. 3b, lane 2), appears to be present in alligator egg albumen (Fig. 3a, lane 4) and is slightly greater in $M_{r}$ than ovalbumin in chicken albumen (band f; Fig. 3a, lane 5).

\section{Two-dimensional SDS-PAGE}

Infundibulum of vitellogenic alligators. Representative fluorographs of polypeptides synthesized de novo and secreted into culture medium by anterior and posterior infundibulum tissue explants (Table 3) are shown (Fig. 4a,b). The infundibulum appears to synthesize and secrete a complex array of proteins during vitellogenesis. The major vitellogenic alligator protein 1 (aP1), common to both anterior and posterior segments, is a $55000 M_{r}$ basic protein ( $\mathrm{pI}>8.0$ ) that corresponds to band a (Fig. 2a,b). A protein family (aP2; $\left.M_{r} 27000-29000\right)$ with at least four isoelectric species is also common to both infundibulum segments, although it appears to be a relatively minor constituent in this animal. A very acidic protein (aP3, $M_{r} 28000-35000 ; \mathrm{pI} \leq$ 4 ), with at least three different $M_{r}$ species and aP16 (M $19000 ; \mathrm{pl}>8$ ) are consistently visible only in culture medium conditioned by the anterior infundibulum. In contrast, a basic protein complex $\left(\mathrm{aP} 10, M_{\mathrm{r}}>97000 ; \mathrm{pI}>8\right)$ appears to be variable in appearance and is found only in posterior infundibulum- and upper tube-conditioned culture medium. 

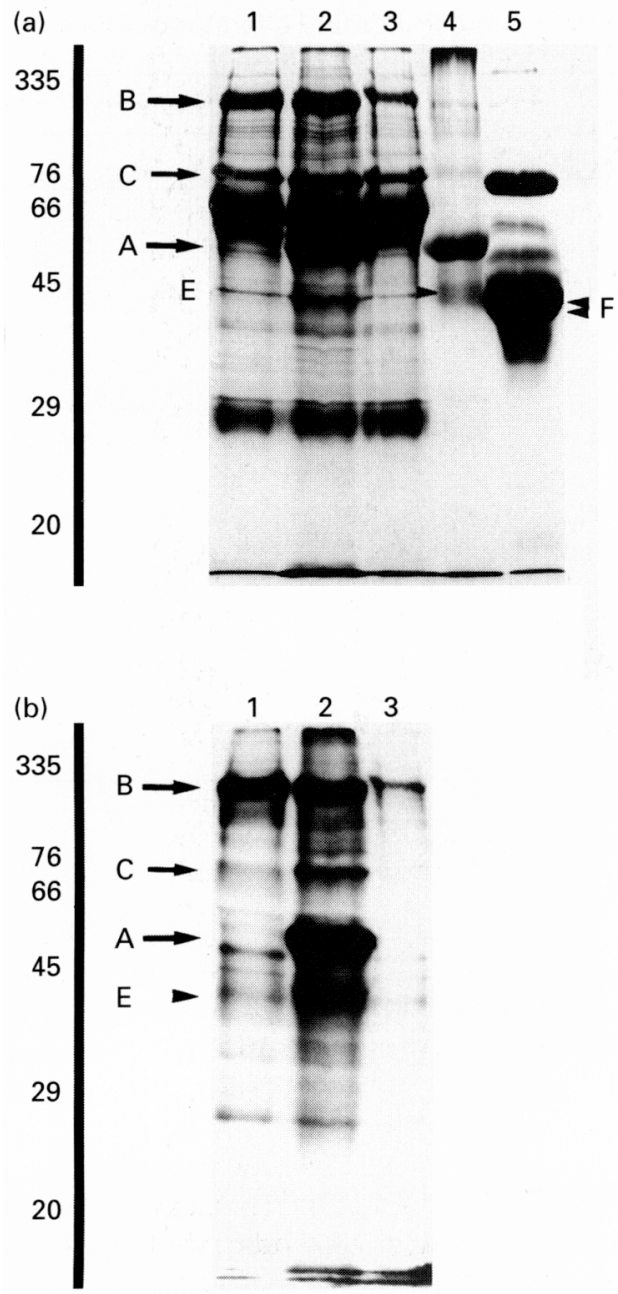

Fig. 3. Comparison of alligator (Alligator mississippiensis) and chicken egg albumens and explant culture media conditioned by vitellogenic alligator reproductive tract tissue after one-dimensional SDS-PAGE separation of proteins. (a) Explant culture media conditioned by lane 1: posterior infundibulum; lane 2: upper tube; lane 3: anterior uterus; lane 4: alligator egg albumen $(200 \mu \mathrm{g})$; lane 5: chicken egg albumen $(200 \mu \mathrm{g})$, stained with Coomassie blue. (b) A representative fluorograph prepared from (a) in which only lanes 1-3 were radiolabelled. Arrows $\mathrm{A}-\mathrm{C}$ and $\mathrm{E}$ represent major radiolabelled bands in (b) and Coomassie blue-stained bands in (a) from reproductive tissue and alligator egg albumen. A minor Coomassie blue-stained band (Fig. 3a, lanes 1-3, E) was a major band in alligator egg albumen (Fig. 3a, lane 4, E, arrowhead) and in the fluorograph (Fig. 3b, lane 2). Band F (Fig. 3a, lane 5, double arrowhead) in chicken egg albumen was slightly lower in $M_{r}$ and was identified as ovalbumin. Molecular mass standards (kDa) are indicated.

These results indicate a differential expression of certain oviductal proteins.

Tube and tubo-uterine junction of vitellogenic alligators. Representative fluorographs of proteins synthesized and secreted by these regions of the tube are shown (Fig. 4c-f; Table 3). Protein aP1, a major protein in the infundibulum of this animal, is also a major protein in the tube of other animals (see Fig. $2 b$, band a). Protein aP2 appears to be ubiquitous throughout the tube and variable among animals. A slightly acidic (pI 6.0) $78000 M_{r}$ protein (aP8) (corresponding to band $\mathrm{c}$ in Fig. $2 \mathrm{~b}$ ) appears to increase in intensity from the tube to the tubo-uterine junction. Protein complex aP12, similar in molecular weight to protein aP1, was visible across a wide $\mathrm{pI}$ range ( $\mathrm{pI} 5-8$ ), present in tube-conditioned medium and may be composed of several proteins. One group of this complex appeared to consist of three isoelectric species at the same $\mathrm{pI}$ as albumin but lower in $M_{\mathrm{r}}$. Other labelled products in this group appear to be poorly resolved.

A fluorograph representative of tubo-uterine junction tissue is shown (Fig. 4f). Proteins released by this tissue appear to be similar to those released by the tube; aP8 is a major protein in this animal. However, protein aP15 $\left(M_{r}\right.$ $97000 ; \mathrm{pI} 5-6$ ) appears only in the tubo-uterine junction and not the tube.

Anterior and posterior uterus of vitellogenic alligators. Representative fluorographs of the fibre region (anterior uterus) or the calcium region (posterior uterus) are shown (Fig. 4g-i). Major proteins synthesized de novo in these regions (Table 3) from vitellogenic animals include aP4 $\left(M_{\mathrm{r}}\right.$ $60000, \mathrm{pI}>7.5), \mathrm{aP5}\left(M_{\mathrm{r}} 60000, \mathrm{pI} 7.5\right), \mathrm{aP6}\left(M_{\mathrm{r}} 66000, \mathrm{pI} 6\right)$, and aP7 $\left(M_{\mathrm{r}} 71000, \mathrm{pI} 5\right)$. An enlargement of a corresponding fluorograph from another vitellogenic alligator (Fig. $4 \mathrm{~g}$ inset) shows that aP4 and aP5 are separate and distinguishable proteins. A second complex of proteins, aP9, arranged as a band between $M_{r} 25000$ and 29000 , extends nearly across the width of the $\mathrm{pH}$ range used for separation and contains a large number of proteins. Protein aP2, found in both anterior and posterior uterus, does not appear to be a major protein in the uterus of the animal shown, but it is variably found as a major protein in other vitellogenic animals (Fig. 4i, inset). In some animals, aP2 appears to be more intense in the uterus than in other regions of the tract. Protein aP14 $\left(M_{r}<12000\right)$ with three isoforms is a minor protein of vitellogenic animals in the anterior and posterior uterus (Fig. 4h, inset, i).

Infundibulum of gravid, post-clutch, and non-reproductive animals. Although animals within these three reproductive stages appeared to synthesize and secrete a similar complex array of proteins (Tables 3 and 4) in the infundibulum, differences with vitellogenic alligators were observed. Protein aP1, a major protein in vitellogenic animals, was either produced here in trace amounts or not at all by the anterior infundibulum, while protein aP10 appeared as a minor protein in the posterior infundibulum. Only the nonreproductive group produced proteins aP4-7, heavy chain immunoglobulins (see below) and aP9 in the infundibulum.

Tube and tubo-uterine junction of gravid, post-clutch, and non-reproductive animals. Protein aP1 appeared only as a trace protein in the upper region of the tube in the gravid and post-clutch groups and was not present in nonreproducing alligators. Proteins aP2 and aP8, variable with reproductive status and among animals, was present throughout the tube. Protein aP12 was either minor or not found at all in this group. Proteins aP4-7, immunoglobulins 
Table 3. Properties and origin of the secretory proteins of the vitellogenic and gravid alligator oviduct

\begin{tabular}{|c|c|c|c|c|c|c|c|c|c|c|c|c|c|c|}
\hline \multirow{2}{*}{$\begin{array}{l}\text { Alligator } \\
\text { protein }\end{array}$} & \multicolumn{2}{|c|}{ Properties } & \multicolumn{6}{|c|}{ Vitellogenic segments ${ }^{a}$} & \multicolumn{6}{|c|}{ Gravid segments ${ }^{a}$} \\
\hline & $M_{\mathrm{r}}$ & $\mathrm{pI}$ & 1 & 2 & 3 & 4 & 5 & 6 & 1 & 2 & 3 & 4 & 5 & 6 \\
\hline $\mathrm{aP1}$ & 55000 & $>8$ & t+ & t+ & t+ & + & - & - & - & + & + & - & - & - \\
\hline $\mathrm{aP2} 2$ & $27000-29000$ & $5-6$ & - & + & t+ & + & + & + & + & + & + & + & t+ & +t \\
\hline $\mathrm{aP3}$ & $28000-35000$ & $<4$ & t+ & - & - & - & - & - & + & - & - & - & - & - \\
\hline $\mathrm{aP} 4$ & 60000 & $>8$ & - & - & - & - & ++ & +t & - & - & - & - & - & - \\
\hline aP5 & 60000 & 7.5 & - & - & - & - & ++ & ++ & - & - & - & - & - & - \\
\hline $\mathrm{aP6}$ & 66000 & 6 & - & - & - & - & t+ & +t & - & - & - & - & - & - \\
\hline $\mathrm{aP7}$ & 71000 & 5 & - & - & - & - & t+ & ++ & - & - & - & - & - & - \\
\hline aP8 & 78000 & 6 & - & + & +t & ++ & - & - & - & + & ++ & + & - & - \\
\hline aP9 & $25000-29000$ & $5-8$ & - & - & - & - & t+ & t+ & - & - & - & - & - & - \\
\hline aP10 & $>97000$ & $>7$ & - & + & + & + & - & - & + & + & + & + & + & + \\
\hline aP11 & 29000 & $>8$ & - & - & + & - & - & - & - & - & - & - & - & - \\
\hline aP12 & 55000 & 5-8 & - & - & ++ & - & - & - & + & + & - & - & - & - \\
\hline $\mathrm{aP} 13$ & 40000 & $4-5$ & + & + & ++ & + & - & + & + & + & + & + & + & + \\
\hline aP14 & $<12000$ & $6-8$ & - & - & + & + & + & + & - & - & + & + & +t & ++ \\
\hline aP15 & 97000 & $5-6$ & - & - & - & + & + & + & - & - & - & + & ++ & ++ \\
\hline $\mathrm{aP} 16$ & 19000 & $>8$ & + & - & - & - & - & - & + & - & - & - & - & - \\
\hline
\end{tabular}

"Numbers 1-6 represent oviductal regions shown in Fig. 1.

++ , fluorographic intensity was very great; + , detectable in all specimens by fluorography; - , not detectable by fluorography.

and aP9 are produced only by the non-reproducing group in the tube.

The expression of proteins in the tubo-uterine junction of gravid females was similar to that in the tube and uterus during this stage. However, those proteins produced by the tubo-uterine junction in the post-clutch group were more similar to proteins expressed by the anterior and posterior uterus in vitellogenic animals.

Anterior and posterior uterus of gravid, post-clutch, and nonreproductive animals. Proteins aP4-aP7 were not expressed by the gravid or post-clutch groups. However, these were the major proteins expressed by anterior and posterior uterus in non-reproducing alligators.

Proteins aP2, aP13 and aP14, minor proteins of vitellogenic and non-reproducing alligators (Tables 3 and 4) appeared to be major proteins synthesized and secreted in these regions by gravid (Fig. $4 \mathrm{~h}, \mathrm{i}$ ) and post-clutch animals.

\section{Immunoblot analysis}

Proteins in explant culture medium, conditioned by tissue from the upper tube region of a vitellogenic alligator, were separated by two-dimensional SDS-PAGE, transferred to PVDF membranes and membranes incubated with either rabbit anti-oligopeptide or pre-immune serum are shown (Fig. 5a,b). Antibody directed against the synthetic oligopeptide representing the $\mathrm{N}$-terminal region of aP1 immunoreacted with protein aP1, protein that extends to $\mathrm{aP} 12$, and a protein identified as aP11 $\left(31000 \mathrm{M}_{\mathrm{r}} ; \mathrm{pI}>8.0\right)$. Immunostaining demonstrated several isoelectric species of $\mathrm{aP} 1$ and $\mathrm{aP} 11$ that were not seen by fluorography, indicating that these may be minor processed or truncated proteins. In addition, immunostaining of aP12 indicated that aP1 and aP12 are related or share one or more epitopes.

\section{$N$-terminal amino acid microsequence analysis}

Proteins aP1, aP4-7 and aP11, purified by twodimensional SDS-PAGE, were transferred onto Immobilon PVDF membranes and subjected to N-terminal amino acid microsequencing. A 29 amino acid sequence for aP1 was positively identified. Comparison of this sequence with previously identified protein, RNA, or DNA sequences using the BLAST P program did not reveal a significant overlap or identity to any other known protein, RNA or DNA sequences. However, this sequence matched the major protein comprising alligator egg albumen (L. Guillette and E. Walworth, unpublished) (Table 5).

For each of the proteins aP4-7, 26 amino acid residues were identified, consisting of 23 positively identified residues and three unknowns (Table 6). Each $\mathrm{N}$-terminal sequence was found to be identical to the others. Comparison of these sequences to other known protein, RNA or DNA databases revealed a significant similarity to the immunoglobulin (Ig) heavy chain region from several species. The $\mathrm{N}$-terminal 23 amino acid sequence of each had $74 \%$ identity and $91 \%$ similarity with human Ig heavy chain variable region (Genbank accession number P01824) and $63 \%$ identity and $84 \%$ similarity to Caiman crocodile $\mathrm{Ig}$ heavy chain region (Genbank accession number P 03982). High similarities were also demonstrated with Ig heavy chain $V$ regions of other species.

Protein aP11 was transferred to PVDF membrane and 25 amino acids were positively identified. These amino acids were $100 \%$ identical to the first 25 amino acids of aP1 (Table 3 ). 


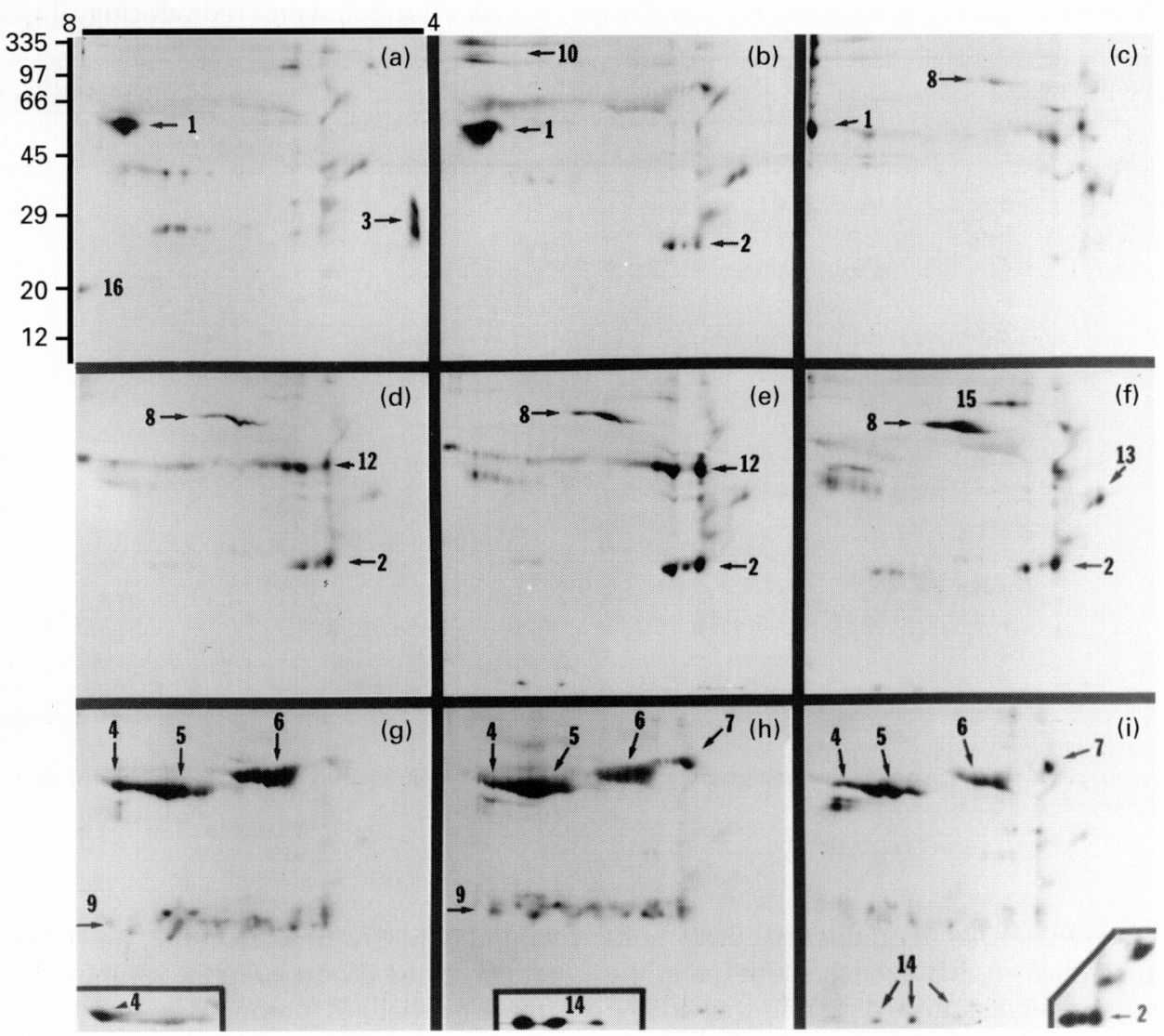

Fig. 4. Representative fluorographs from a two-dimensional SDS-PAGE analysis of explant culture medium conditioned by tissue from the reproductive tract of a vitellogenic alligator, Alligator mississippiensis. Panels represent explant medium (50000 c.p.m. $\left[{ }^{3} \mathrm{H}\right] \mathrm{Leu}$ ) from (a) anterior infundibulum, (b) posterior infundibulum, (c) upper tube, (d) middle tube, (e) lower tube, (f) tubo-uterine junction, $(\mathrm{g})$ anterior uterus, $(\mathrm{h})$ lower anterior uterus, and (i) posterior uterus. Numbers indicate specific proteins. Insets in $(\mathrm{g}),(\mathrm{h})$, and (i) represent labelled proteins from other alligators. Molecular mass standards $(\mathrm{kDa})$ are indicated. The $\mathrm{pH}$ gradient is indicated from $\mathrm{pH} 4$ (right) to $\mathrm{pH} 8$ (left).

\section{Total amino acid analysis}

Protein aP1 purified by two-dimensional SDS-PAGE and western blotting was subjected to total amino acid analysis. Those results demonstrated a very high lysine content consistent with the demonstrated basic $\mathrm{pI}$ of this protein.

\section{Discussion}

The present study is the first detailed analysis of the biosynthetic activity and characterization of proteins expressed by the reproductive tract of American alligators including investigation of different reproductive states. The different functional regions of the reproductive tract were shown to synthesize de novo and release a complex array of proteins into culture media. The presence and distribution of some proteins appear to be dependent on the specific region of the reproductive tract and the reproductive status, while the biosynthetic activity of the tract appeared, in some cases, to be dependent on an interaction between region and reproductive status. As an example, the biosynthetic activity of the infundibulum and tube in vitellogenic, gravid and post-clutch animals was significantly greater than that of the tubo-uterine junction and uterus, while the activity of the posterior infundibulum was significantly greater than that of the tube. Therefore, the higher synthetic activity of the infundibulum is consistent with the synthetic production and deposition of large quantities of albumen around the oocyte-embryo during its passage through the tube (Palmer and Guillette, 1991). Muramatsu et al. (1991) showed significantly greater synthesis of total protein and ovalbumin in a specific oviductal segment in laying hens when an ovum was present in that segment. This difference was mainly attributable to an increase in protein synthesis in the magnum.

The biosynthetic activity of the anterior region of the tract (infundibulum and tube), while similar across all groups, was always greater than that of the posterior region (tubo-uterine junction and uterus), except in the nonreproducing group. In this group, the posterior region (tubo-uterine junction and uterus) was not different from the anterior region. This difference in biosynthetic activity of the 
Table 4. Properties and origin of the secretory proteins of the post-clutch and non-reproducing alligator oviduct

\begin{tabular}{|c|c|c|c|c|c|c|c|c|c|c|c|c|c|c|}
\hline \multirow{2}{*}{$\begin{array}{l}\text { Alligator } \\
\text { protein }\end{array}$} & \multicolumn{2}{|c|}{ Properties } & \multicolumn{6}{|c|}{ Post-clutch segments ${ }^{a}$} & \multicolumn{6}{|c|}{ Non-reproducing segments ${ }^{a}$} \\
\hline & $M_{\mathrm{r}}$ & $\mathrm{pI}$ & 1 & 2 & 3 & 4 & 5 & 6 & 1 & 2 & 3 & 4 & 5 & 6 \\
\hline $\mathrm{aP1}$ & 55000 & $>8$ & + & + & + & - & - & - & - & - & - & & - & - \\
\hline $\mathrm{aP2}$ & $27000-29000$ & $5-6$ & - & + & + & + & + & + & + & + & + & & + & + \\
\hline $\mathrm{aP3}$ & $28000-35000$ & $<4$ & ++ & + & - & - & - & - & + & - & - & & - & - \\
\hline $\mathrm{aP} 4$ & 60000 & $>8$ & - & - & - & + & + & + & \pm & \pm & + & & ++ & ++ \\
\hline $\mathrm{aP} 5$ & 60000 & 7.5 & - & - & - & + & + & + & \pm & \pm & + & & ++ & ++ \\
\hline aP6 & 66000 & 6 & - & - & - & + & + & + & \pm & \pm & + & & ++ & ++ \\
\hline $\mathrm{aP7}$ & 71000 & 5 & - & - & - & + & + & + & \pm & \pm & + & & ++ & ++ \\
\hline $\mathrm{aP8}$ & 78000 & 6 & - & + & $+t$ & + & - & - & - & - & + & & - & - \\
\hline $\mathrm{aP9}$ & $25000-29000$ & 5-8 & - & - & - & + & - & - & \pm & \pm & + & & ++ & ++ \\
\hline $\mathrm{aP} 10$ & $>97000$ & $>7$ & + & + & - & + & - & - & - & + & + & & - & - \\
\hline $\mathrm{aP} 11$ & 29000 & $>8$ & - & - & - & - & - & - & - & - & - & & - & - \\
\hline $\mathrm{aP} 12$ & 55000 & $5-8$ & - & - & - & - & + & + & - & + & + & & - & - \\
\hline $\mathrm{aP} 13$ & 40000 & $4-5$ & + & + & + & + & + & + & + & + & + & & - & - \\
\hline $\mathrm{aP} 14$ & $<12000$ & $6-8$ & + & + & + & + & + & ++ & - & - & - & & + & + \\
\hline $\mathrm{aP} 15$ & 97000 & $5-6$ & - & - & - & + & + & + & - & - & - & & - & - \\
\hline $\mathrm{aP} 16$ & 19000 & $>8$ & + & + & - & - & - & - & + & - & + & & - & - \\
\hline
\end{tabular}

${ }^{2}$ Numbers 1-6 represent oviductal regions shown in Fig. 1.

\pm , present in most but not all specimens; ++ , fluorographic intensity of protein was very great; + , protein detectable in all specimens by fluorography; - , protein not detectable in all or most specimens by fluorography.

posterior region between the reproductive and nonreproductive groups indicated that protein synthesis in the posterior region was regulated in a different way in the non-reproductive group. The increased overall biosynthetic activity in the non-reproductive group, as well as in the posterior region specifically, may contribute to the nonreproductive status of this group of alligators.

Analyses of explant culture media, conditioned by different functional regions, by two-dimensional SDS-PAGE revealed a complex pattern of proteins. Certain proteins synthesized de novo appeared to be restricted to specific functional regions of the tract. Specifically, expression of aP1, the major vitellogenic alligator reproductive tract protein, was greatest in the posterior infundibulum and tube region and was not found in cultures of tubo-uterine junction or uterine tissue. Protein aP3, restricted to the anterior infundibulum, and aP16, found only in the infundibulum (except in the non-reproductive group), were found in all reproductive groups. Proteins aP4-7, related to mammalian immunoglobulin heavy chains, were found to be major products of the anterior and posterior uterus in vitellogenic and non-reproducing alligators, but minor products of postclutch alligators and were not produced by gravid alligators. Proteins aP4-7 were also significant in the infundibulum and tube of non-reproductive alligators. These data indicate a differential expression of reproductive tract proteins on the basis of reproductive status and oviductal region. All other proteins appeared to be produced by all regions of the tract. However, regional changes in intensity, as well as variation among reproductive stages, could suggest potential synthetic gradients.

In birds, formation of albumen proteins occurs in all functional regions, although the majority of proteins are produced by the magnum and initial layers by the infundibulum (Muramatsu et al., 1991). Egg shell membranes and fibres are produced in the isthmus and the calcium layer (the egg shell) is produced in the shell gland. Thus, the biosynthetic activity of the alligator tract, the distribution of proteins synthesized and released, and morphological and histological evidence indicate that the alligator tract represents an evolutionary intermediate form between birds and ancestral oviparous amniotes (Palmer and Guillette, 1992).

The present study and that of Palmer and Guillette (1991) examined and compared egg albumen proteins in reptiles and birds by gel electrophoresis. Substantial $M_{\mathrm{r}}$ differences among the various albumen proteins were observed and certain expected proteins were absent. A similar comparison between egg albumens of estuarine crocodiles and those of laying hens showed that the major hen egg proteins, ovalbumin and ovotransferrin, were not detected in crocodile albumen (Burley et al., 1987). Ovalbumin appears to be a relatively minor protein in alligator egg albumen (Rose et al., 1990), if it is present at all. Furthermore, in the present study, no major protein synthesized by the oviduct was detected that was similar to ovalbumin (45000 $M_{r^{\prime}}$ pI 5.4). Several proteins in this $M_{\mathrm{r}}$ range were observed but they are relatively minor components. The major albumen protein identified by electrophoretic studies of alligator egg albumen (Palmer and Guillette, 1991) was $59000 M_{r}$. In the egg albumen of crocodiles, a $59000 M_{r}$ unidentified protein was also detected (Burley et al., 1987). These egg albumen proteins correspond to the vitellogenic oviductal protein aP1 (55000 $M_{r}$ ), found in oviductal explant medium, as demonstrated by comparison of N-terminal amino acid sequences (L. Guillette and E. Walworth, unpublished). These data demonstrate that the major alligator egg albumen protein $(59 \mathrm{kDa})$ is derived from the infundibulum and oviductal tube, and ovalbumin 


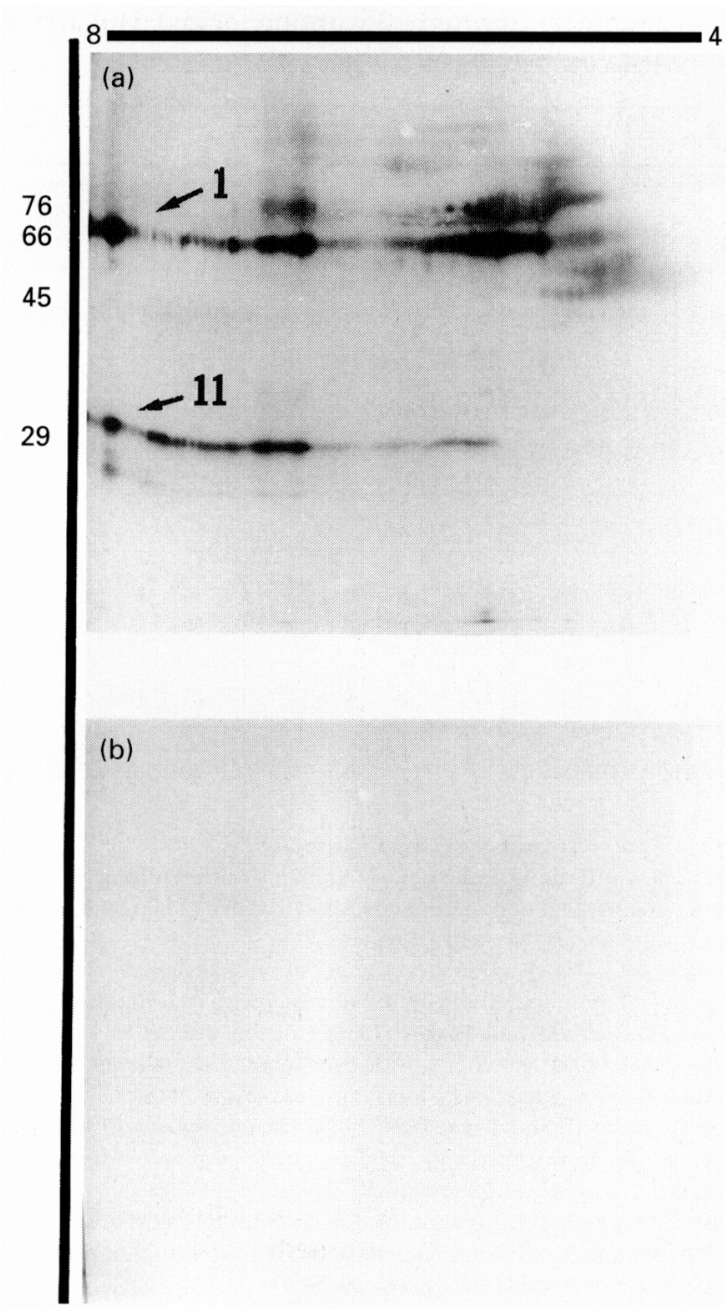

Fig. 5. Western blot analysis of alligator protein 1 (aP1) with antioligopeptide serum. Proteins in upper tube-conditioned media from a vitellogenic alligator, Alligator mississippiensis, were separated by two-dimensional SDS-PAGE and transferred to Immobilon PVDF membrane. (a) Blot was treated with rabbit anti-oligopeptide serum (1:200) while (b) a parallel blot was treated with pre-immune serum (1:200) and developed. Arrows indicate the location of aP1 and aP11. The $\mathrm{pH}$ gradient from $\mathrm{pH} 4$ (right) to $\mathrm{pH} 8$ (left) and molecular mass standards $(\mathrm{kDa})$ are indicated.

presumably replaces aP1-like proteins as the major egg albumen protein in birds.

Protein aP8, which corresponds to ovotransferrin (Stevens, 1991) by $M_{r}$, is found to be produced primarily by the tube and posterior infundibulum, but not by the uterus. A similar protein found in alligator egg albumen (Palmer and Guillette, 1991) has been identified by immunoblot analysis as ovotransferrin (L. Guillette and E. Walworth, unpublished), indicating that synthesis by the tube is the primary source of this protein.

Four major anterior and posterior uterus proteins (aP4-7) were shown to have a significant sequence similarity to the immunoglobulin heavy chain found in a number of species, while the pattern and distribution of protein aP9 is similar to that demonstrated for immunoglobulin light chains in mammals (Latner et al., 1980; Anderson, 1981). Synthesis de novo and release of immunoglobulins into media conditioned by anterior and posterior uterus tissue indicates the presence of plasma cells in these regions. Plasma cells and immunoglobulin synthesis has been documented in both mammalian and chicken reproductive tract tissue (Hussein et al., 1983; Wira and Sullivan, 1985; Kutteh et al., 1988; Buhi et al., 1989b; Kimijima et al., 1990) and data indicate a regulation of plasma cell entry and immunoglobulin synthesis by oestrogen and progesterone (Wira and Sullivan, 1985). The presence of immunoglobulin-like proteins in uterine cultures from vitellogenic, post-clutch and non-reproductive, but not gravid, females indicates a differential expression of these proteins and potential control by unknown factors. In addition, the presence of proteins aP4-7 and aP9 in infundibulum and tube cultures coupled with increased biosynthetic activity in non-reproductive group animals may explain, in part, why these alligators were non-reproductive. This finding may also explain why the infundibulum and tube biosynthetic activity is increased in the non-reproductive group, as well as the apparent lack of regulation of the biosynthetic activity. In the anterior and posterior uterus, biosynthetic activities are generally thought to be associated with the production of the proteinaceous fibre for eggshell membrane and eggshell calcification rather than albumen synthesis (Palmer and Guillette, 1992). Given the environment of the alligator, production of immunoglobulins by the reproductive tract may be a protective mechanism to inhibit infection and the disruption of reproduction. However, immunoglobulins have also been found in chicken egg yolk and egg white, and transfer of immunity from the maternal system to the young by way of the egg has been proposed (Kimijima et al., 1990). Whether immunoglobulins become part of alligator egg albumen or yolk remains to be determined.

Several other proteins have been identified directly or indirectly as being products of the alligator or crocodile reproductive tract. Insulin-like growth factor-I is present in serum and eggs (Guillette et al., 1996) and has been immunolocalized in the infundibulum and tube, the anterior uterus and the posterior uterus (Cox and Guillette, 1993). Ovomacroglobulin has been purified from crocodile egg white and its properties compared with both chicken ovomacroglobulin and human alpha-2-macroglobulin (Ikai et al., 1983; Nishigai et al., 1985; Arakawa et al., 1986). Whether these are products synthesized by the oviduct remains to be determined, although their presence in egg albumen implies that this is the case.

While it was apparent from this study that ovalbumin is lacking in alligator egg albumen, a second difference noted between alligators and chickens is that biotin-, riboflavin-, and thiamin-binding proteins are not found in egg albumen as they are in birds (Abrams et al., 1989), implying differences among species in oviductal gene expression.

On the basis of oviductal and egg albumen from the present and other (L. Guillette and E. Walworth, unpublished) studies, it is suggested that the major alligator egg albumen protein is the basic $55000 M_{r}$ oviductal protein, aP1, and that this protein is unrelated to the avian albumen protein, 
Table 5. N-terminal amino acid sequence of alligator protein aP1 (and aP11 through 25 amino acids) isolated from infundibulum-conditioned culture media from a vitellogenic alligator

Amino acid position

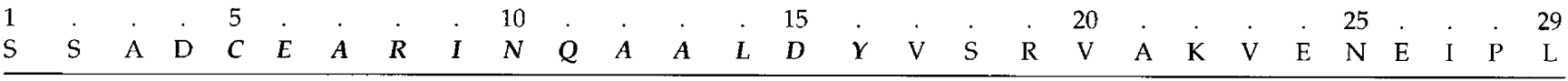

A synthetic (12-mer) oligopeptide (amino acids 5-16) was synthesized by the Interdisciplinary Center for Biotechnology Research, coupled to keyhole limpet haemocyanin and injected into rabbits to prepare antibody specific to aP1.

Table 6. Comparison of $\mathrm{N}$-terminal amino acid microsequence analysis of alligator proteins aP4-7 isolated from vitellogenic alligator uterine-conditioned culture medium to that of human Ig heavy chain V-II region

Amino acid position

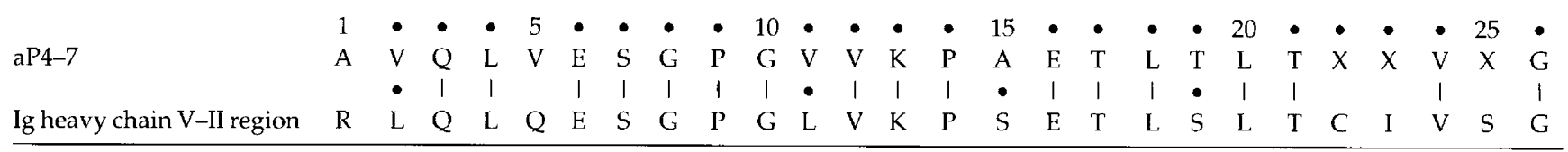

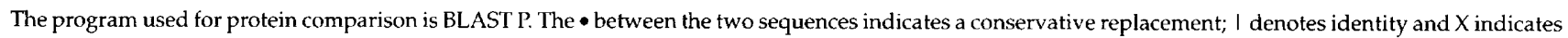
an unidentified amino acid.

ovalbumin. Protein aP1 and other proteins are produced by the infundibulum and tube and form the albumen that is deposited around the developing oocyte-embryo as it moves through the tract. The role or function of aP1 in embryo growth and development is unknown and remains to be examined. The significance of immunoglobulin production by the uterus, and the infundibulum and tube in nonreproductive alligators, is also unknown but it may be that the alligator reproductive tract is, as has been described for mammals and suggested for chickens, part of the secretory immune system. Furthermore, immunoglobulin production by non-reproducing alligators may play a role in their non-reproductive status and should be investigated. Other oviduct-derived proteins found have not yet been identified and it remains to be determined whether they are similar to proteins in birds, other reptiles and mammals. The identification and characterization of reproductive tract and egg albumen proteins will permit a better understanding of the evolution of alligator albumen, its relationship to other egg albumens, and potentially its physiological functions in the oviductal and embryonic environment.

The authors acknowledge M. Moser, B. Palmer, and past and present graduate students, undergraduates and associates in the laboratory of L. J. Guillette, Jr, for their valuable assistance in this study. They are grateful to $W$. Thatcher, Department of Dairy and Poultry Science, for his assistance with the statistical evaluation. This study was supported in part by NIH HD20553 (W. C. Buhi), USDA 92-37203-7996 (W. C. Buhi and F. A. Simmen), Florida Game and Freshwater Fish Commission (L. J. Guillette, Jr)

\section{References}

Abrams VAM, Bush L, Kennedy T, Schreiber RW, Jr, Sherwood TA and White HB, III (1989) Vitamin-transport proteins in alligator eggs Comparative Biochemistry and Physiology 93B 291-297

Altschul SE, Gish W, Miller W, Myers EW and Lipman DJ (1990) Basic local alignment search tool fournal of Molecular Biology 215 403-410
Alvarez IM, Guillette LJ and Buhi WC (1992) In vitro synthesis and secretion of proteins by alligator reproductive tract during vitellogenesis Biology of Reproduction 46 (Supplement 1) 76

Anderson NL (1981) High resolution two-dimensional electrophoretic mapping of immunoglobulin light chains Immunology Letters 2 195-199

Arakawa H, Osada T and Ikai A (1986) Unusual properties of crocodilian ovomacroglobulin shown in its methylamine treatment and sulfhydryl titration Archives of Biochemistry and Biophysics $244447-453$

Buhi WC, Vallet JL and Bazer FW (1989a) De novo synthesis and release of polypeptides from cyclic and early pregnant porcine oviductal tissue in explant culture Journal of Experimental Zoology 252 79-88

Buhi WC, Van Wert JW, Alvarez IM, Dones-Smith MM and Bernhisel MA (1989b) Synthesis and secretion of proteins by postpartum human oviductal tissue in culture Fertility and Sterility 51 75-80

Buhi WC, Alvarez IM, Sudhipong V and Dones-Smith MM (1990) Identification and characterization of de novo synthesized porcine oviductal secretory proteins Biology of Reproduction 43 929-938

Burley RW, Back JF, Wellington JE and Grigg GC (1987) Proteins of the albumen and vitelline membrane of eggs of the estuarine crocodile, Crocodylus porosus. Comparative Biochemistry and Physiology 88B 863-867

Cox C and Guillette LJ, Jr (1993) Localization of insulin-like growth factor-1like immunoreactivity in the reproductive tract of the vitellogenic female American alligator, Aligator mississippiensis. Anatomical Record 236 635-640

Guillette LJ, Woodward AR, Qui Y-X, Cox MC, Matter JM and Gross TS (1995) Formation and repression of the corpus luteum of the American alligator (Alligator mississippiensis) Journal of Morphology 224 97-110

Guillette LJ, Cox MC and Crain DA (1996) Plasma insulin-like growth factor-I concentration during the reproductive cycle of the American alligator (Alligator mississippiensis) General and Comparative Endocrinology 104 116-122

Guillette LJ, Woodward AR, Crain DA, Masson GR, Palmer BD, Cox MC, Qui Y-X and Orlando EF (1997) The reproductive cycle of the American alligator (Alligator mississippiensis) General and Comparative Endocrinology 108 $87-101$

Harlow E and Lane D (1988) Antibodies: A Laboratory Manual Cold Spring Harbor Laboratory, Cold Spring Harbor, NY

Hussein AM, Newby TJ and Bourne FJ (1983) Immunohistochemical studies of the local immune system in the reproductive tract of the sow Journal of Reproductive Immunology 5 1-15

Ikai A, Kitamoto T and Nishigai M (1983) Alpha-2-macroglobulin-like protease inhibitor from the egg white of Cuban crocodile (Crocodylus rhombifer) Journal of Biochemistry 93 121-127

Joanen T and McNease L (1989) Ecology and physiology of nesting and early development of the American alligator American Zoologist 29 987-998

Kimijima T, Hashimoto Y, Kitagawa H, Kon Y and Sigimura M (1990) Localization of immunoglobulins in the chicken oviduct Japanese Journal of Veterinary Science $\mathbf{5 2}$ 299-305 
Kutteh W, Hatch K, Blackwell R and Mestecky J (1988) Secretory immune system of the female reproductive tract I. Immunoglobulin and secretory component-containing cells Obstetrics and Gynecology 71 56-60

Lance VA (1989) Reproductive cycle of the American alligator American Zoologist 29 999-1018

Latner AL, Marshall T and Gambie M (1980) Simplified technique of high resolution two-dimensional electrophoresis: serum immunoglobulins Clinica Chimica Acta 103 51-59

Muramatsu T, Hiramoto K and Okumura J-I (1991) Changes in ovalbumin and protein synthesis in vivo in the magnum of laying hens during the egg formation cycle Comparative Biochemistry and Physiology 99B 141-146

Nishigai M, Osada T and Ikai A (1985) Structural changes in alpha-2and ovomacroglobulins studied by gel chromatography and electron microscopy Biochimica et Biophysica Acta 831 236-241

Ogilvie S, Duckworth ML, Larkin LH, Buhi WC and Shiverick KT (1990) De novo synthesis and secretion of prolactin-like protein $\mathrm{B}$ by rat placental explants Endocrinology 126 2561-2566

Palmer BD and Guillette LJ (1991) Oviductal proteins and their influence on embryonic development in birds and reptiles. In Physical Influences on Embryonic Development in Birds and Reptiles pp 29-46 Eds MWJ Ferguson and DC Deaming. Cambridge University Press, Cambridge

Palmer BD and Guillette LJ (1992) Alligators provide evidence for the evolution of an Archosaurian mode of oviparity Biology of Reproduction 46 39-47
Pearson WR and Lipman DJ (1998) Improved tools for biological sequence comparison Proceedings National Academy of Sciences USA 85 2444-2448

Roberts RM, Baumbach GA, Buhi WC, Denny JB, Fitzgerald LA, Babalyn SF and Horst MN (1984) Analysis of membrane polypeptides by twodimensional polyacrylamide gel electrophoresis. In Molecular and Chemical Characterization of Membrane Receptors pp 61-113 Eds CJ Ventor and LC Harrison. AR Liss, New York

Rose FL, Paxton R and Britton CH III (1990) Identification of an ovalbuminlike protein in egg-white of turtle and alligator Comparative Biochemistry and Physiology 96B 651-654

SAS (1989) SAS/STAT User's Guide Version 6 Statistics Statistical Analysis System Institute Inc., Cary, NC

Schägger H and von Jagow G (1987) Tricine-sodium dodecyl sulfatepolyacrylamide gel electrophoresis for the separation of proteins in the range from 1 to $100 \mathrm{kDa}$ Analytical Biochemistry 166 368-379

Stevens L (1991) Egg white proteins Comparative Biochemistry and Physiology 100B 1-9

Wira CR and Sullivan DA (1985) Estradiol and progesterone regulation of immunoglobulin $A$ and $G$ and secretory component in cervicovaginal secretion in the rat Biology of Reproduction 32 90-95

Woodward AR, Jennings ML and Percival HF (1989) Egg collecting and hatch rates of American alligator eggs in Florida Wildlife Society Bulletin 17 $124-130$ 